\title{
Rethinking the History of Repair:
}

\section{Repair Cultures and the "Lifespan" of Things}

\author{
Stefan Krebs and Heike Weber
}

The act of repair is inherent to everyday life. ${ }^{1}$ Repair processes are inextricably linked not only to the things we repair, but also to infrastructures and organisational processes. Repair practices therefore play a vitally important role in reciprocal interactions between humans and technology - a role associated with highly specific knowledge about things, equipment, processes and interventions. Steven Jackson describes his article "Rethinking Repair" as an exercise in "broken world thinking". ${ }^{2}$ In so doing, he employs a methodological principle which Geoffrey Bowker has coined as "infrastructural inversion", ${ }^{3}$ i. e. "learning to look closely at technologies and arrangements that, by design and by habit, tend to fade into the woodwork" ${ }^{4}$ When Jackson examines the act of repair, he therefore posits that the normal state is for a system to be fundamentally broken rather than for it to be functioning properly. Only from this perspective does it become clear that certain systems (in particular major infrastructure systems such as gas,

1 This is a translated and abridged version of Krebs, Stefan/Schabacher, Gabriele/Weber, Heike: "Kulturen des Reparierens und die Lebensdauer der Dinge", in: id. (eds.): Kulturen des Reparierens: Dinge - Wissen - Praktiken, Bielefeld: transcript 2018, p. 9-46.

2 Jackson, Steven J.: "Rethinking Repair", in: Gillespie, Tarleton/Boczkowski, Pablo J./ Foot, Kirsten A. (eds.): Media Technologies. Essays on Communication, Materiality, and Society, Cambridge, MA/London: MIT Press 2014, p. 221-239, here p. 221.

3 Bowker, Geoffrey: "Information Mythology. The World of/as Information", in: BudFrierman, Lisa (ed.): Information Acumen. The Understanding and Use of Knowledge in Modern Business, London/New York: Routledge 1994, p. 231-247.

4 Bowker, Geoffrey/Star, Susan Leigh: Sorting Things Out: Classification and its Consequences, Cambridge, MA/London: MIT Press 1999, p. 34. 
telephone, underground railways, etc.) can be kept up and running solely through never-ending practices of repair and maintenance, since all defects, up to and including system failure, are inherent to them. ${ }^{5}$

Repairs are often unscheduled and arise out of a need to eliminate faults and to make things which have broken down useful again. These criteria distinguish repairs from maintenance, which is a precautionary activity that is generally scheduled in advance. Nevertheless, maintenance and repair tasks do have some points in common - they both postpone the day when a thing wears out to the point at which it becomes unusable, and they both therefore influence the question of wear and tear and the "lifespan" of things, or in other words how long a thing or good is used for and when it should be removed from circulation.

The purpose of this chapter is to historicise the concept of "repairing things" with a view to broadening and redefining the emphasis of current debates on repair as a "new social movement" and the emergence of a "repair society". Such discourses often allude to the technical empowerment of citizens, "convivialism" and sustainability. For example, Andrea Baier et al. regard certain elements of the current repair and do-it-yourself movement as a "post-capitalist practice" characterised by three different features: (1) an ethical interest in opposing capitalism through subsistence, participation, benevolence and post-growth; (2) the sharing of things ("Do It Together" (DIT) as part of Do It Yourself (DIY)); and (3) general access to repair knowledge, promoted by the Internet as a digital commons which makes knowledge that was previously the purview of a few available to everyone. ${ }^{6}$ Indeed, representatives of the repair movement explicitly view themselves as allies in the fight "against short product lifespans". ${ }^{7}$ What is more, they interpret repairs themselves as an expression of growing technical literacy. Wolfgang Heckl also argues in this vein when, in his plea for a new "culture of repair", he emphasises ideas such as self-empowerment, community building and sustainability. ${ }^{8}$

What is missing in most current debates, however, is a sense of the long history of repairing things which saw ups and downs in cultures of repair and self-

5 Jackson, "Rethinking Repair".

6 Baier, Andrea et al.: "Die Welt reparieren: Eine Kunst des Zusammenmachens", in: id. (eds.): Die Welt reparieren. Open Source und Selbermachen als postkapitalistische Praxis, Bielefeld: transcript 2016, p. 34-62.

7 Grewe, Maria: "Reparieren in Gemeinschaft: Ein Fallbeispiel zum kulturellen Umgang mit materieller Endlichkeit”, in: Bihrer, Andreas/Franke-Schwenk, Anja/Stein, Tine (eds.): Endlichkeit. Zur Vergänglichkeit und Begrenztheit von Mensch, Natur und Gesellschaft, Bielefeld: transcript 2016, p. 331-349.

8 Heckl, Wolfgang: Die Kultur der Reparatur, Munich: Hanser 2013. 
repair, as well as the heterogeneity and interrelatedness of the actors involved. For example, the repair cultures of the interwar period, the DIY movement of the 1960s and the environmental movement of the 1970s were motivated by similar concerns for self-empowerment or sustainability. In this chapter, we will draw on examples from Western Europe and North America to highlight some important moments in the history of repair, the intrinsic links between professional and DIY repair practices, discourses on the "lifespan" of things, and changing disposal regimes.

The act of repair has always been an integral aspect of things, organisations and procedures. Viewed in abstract terms, it can be described as a reciprocal relationship between humans and their material environment which is significant in economic, social and cultural terms and ultimately inherent to each of our interactions with the things that populate our environment. ${ }^{9}$ Reinhold Reith regards the act of repair as an "adapted technology" which offers solutions to various challenges faced by society, ranging from resource scarcity and the need to reduce waste to the way in which people spend their leisure time. ${ }^{10}$ The act of repair does not only pertain to the level of technology but also to questions of culture and society: repairing a thing stabilises or readjusts the relationship between the thing and the user and between the thing and society, ${ }^{11}$ and it is always possible for new meanings to be ascribed to the object in the process. ${ }^{12}$

9 Graham, Stephen/Thrift, Nigel: "Out of Order: Understanding Repair and Maintenance", in: Theory, Culture \& Society 24, 3 (2007), p. 1-25; Jackson, "Rethinking Repair"; Schabacher, Gabriele: "Im Zwischenraum der Lösungen. Reparaturarbeit und Workarounds", in: ilinx - Berliner Beiträge zur Kulturwissenschaft 4 (2017), p. XIIIXXVIII.

10 Reith, Reinhold: "Reparieren: Ein Thema der Technikgeschichte?”, in: Reith, Reinhold/Schmidt, Dorothea (eds.): Kleine Betriebe - Angepasste Technologie? Hoffnungen, Erfahrungen und Ernüchterungen aus sozial- und technikhistorischer Sicht, Münster et al.: Waxmann 2002, p. 139-161, p. 161.

11 Orr, Julian: Talking about Machines. An Ethnography of a Modern Job, Ithaca, NY/ London: Cornell University Press 1996; Henke, Christopher: "The Mechanics of Workplace Order: Toward a Sociology of Repair", in: Berkeley Journal of Sociology 44 (1999/2000), p. 55-81.

12 Edgerton, David: The Shock of the Old. Technology and Global History since 1900, Oxford: Oxford University Press 2007; Rosner, Daniela K./Turner, Fred: "Bühnen der Alternativ-Industrie: Reparaturkollektive und das Vermächtnis der amerikanischen Gegenkultur der 1960er Jahre", in: Krebs/Schabacher/Weber, Kulturen des Reparierens, p. 265-279. 
Over the 20th century, the gradual emergence of consumer and throw-away societies meant that people - or rather those living in more affluent regions of the world - attached less and less significance to the concept of repair. This was by no means a linear process, however, with upswings in interest by different actors and at different points during this period. Mass production and consumption therefore did not directly result in a general decline of repair cultures. Rather, the history of repair over this period was characterised by multifaceted changes, relocations and shifts, with individual areas of decline but also individual areas of growth. A different history of repair cultures can be told for each different field of technology, with the added complication that certain eras such as periods of war or crisis were marked by a resurgence in repair and self-repair. In the field of commercial repair, changing cost relationships were a significant driver: in highly developed mass consumption societies, repair tasks which are difficult to standardise took a back seat in the face of ever-lower "buy-new" costs and everhigher labour costs. ${ }^{13}$

In the case of large-scale production plants and infrastructure installations, however, repair and maintenance tasks have continued to play a vital and unavoidable role in extending the working life of technology for as long as possible. ${ }^{14}$ They represent the largely invisible backbone of production, service provision and consumption opportunities, ${ }^{15}$ yet we know surprisingly little about them, since comprehensive statistics as well as historical studies on the number of people employed in repairing or maintaining goods or selling second-hand goods, and the value these people create, are for the most part lacking. Private households also continue to repair and maintain the goods they own, but doing so is no longer the cardinal rule of housekeeping it once was; the sheer number of goods owned by most households means that most people repair only a few selected and valued items. Nevertheless, improvised repairs using quick-fix solutions such as the omnipresent duct tape are still part of our everyday interactions with the things around us, even in the "throw-away" society of the 21 st century. If we step back and adopt a broader perspective, the practice of repairing old devices and continuing to use them has merely tended to shift to different parts of

13 Reith, "Reparieren".

14 Denis, Jérôme/Pontille, David: "Material Ordering and the Care of Things", in: Science, Technology \& Human Values 40, 3 (2015), p. 338-367; Krebs, Stefan: "Memories of a Dying Industry. Sense and Identity in a British Paper Mill", in: The Senses and Society 12, 1 (2017), p. 35-52.

15 Edgerton, Shock of the Old, p. 75-102. 
the world, particularly its poorer regions, which are not typically where the devices were first used. ${ }^{16}$

The act of repair is often held up in contrast to the practices of disposal and new acquisition, and lauded as a "better" alternative to recycling. Much is made of the fact that repairing a thing and recycling it involve two fundamentally different interactions between society and the thing itself: repairing preserves a thing's "thing-ness", whereas recycling destroys it in order to allow the thing to be reused for its materials. Between these two extremes, there are various reuse options based on disassembly of the product into its individual parts and components, some of which may potentially be incorporated at a later stage into other products as part of the repair process. Consequently, the acts of repair and recycling can figure as complementary strategies on the path towards sustainable product use and disposal. When investigating repair cultures, it is therefore important to ask questions about the "lifespan" of things, "cascades of use" for second- or third-hand things, and where exactly disposal is situated in the spectrum between throwing away and recycling. ${ }^{17}$

If we want to assess the relative sustainability of repair and recycling, however, we must do so in the wider context of material flows and disposal pathways. As long ago as the 1970s, environmentalists championed the ecological virtues of repairing a thing instead of producing a new thing in its place, and called for a shift towards longer product lifespans and product repairability. Whereas people had previously been motivated to repair things out of a desire to save resources and be frugal, now they were motivated to do so out of a desire to save the environment. Over the following decades, however, environmental policy focused on the recycling end of the scale rather than the repair end. ${ }^{18}$

16 Edgerton, Shock of the Old; Hahn, Hans P.: "Das 'zweite Leben' von Mobiltelefonen und Fahrrädern. Temporalität und Nutzungsweisen technischer Objekte in Westafrika", in: Krebs/Schabacher/Weber, Kulturen des Reparierens, p. 105-119; Malefakis, Alexis: “Tansanier mögen keine unversehrten Sachen': Reparaturen und ihre Spuren an alten Schuhen in Daressalam, Tansania", in: ibid., p. 303-326.

17 Weber, Heike: “'Entschaffen': Reste und das Ausrangieren, Zerlegen und Beseitigen des Gemachten (Einleitung)", in: Technikgeschichte 81, 1 (2014), p. 1-32.

18 Weber, Heike: Reste und Recycling bis zur "grünen Wende" - Eine Stoff- und Wissensgeschichte alltäglicher Abfälle, Göttingen: Vandenhoeck \& Ruprecht 2021 (forthcoming). 


\section{SHIFTING REPAIR CULTURES, THE MASSIFICATION OF THINGS AND NOVEL WASTE DISPOSAL SYSTEMS}

The history of repair is typically couched in terms of a decline-and-fall story: people from the pre-industrial "society of scarcity" were forced to use strategies of repair, reworking and reuse in order to survive, ${ }^{19}$ whereas members of the "throw-away society" have grown accustomed to using consumer goods on a more superficial or temporary basis and rarely bother to repair a thing because it is cheaper to go out and buy a new one. Furthermore, in pre-industrial society all societal classes repaired things; they were part of an "economy of makeshifts" that was characterised by high material and low labour costs. Yet we believe that it is time to rethink this decline-and-fall story, and below we propose an alternative history of repair - one which emphasises differentiation, multiple upswings and geographical displacement.

There can be little doubt that industrialisation resulted in a shift away from economies of repair to economies of manufacturing virgin products. ${ }^{20}$ At the same time, two of the key factors in the rise of mass consumerism and consumer technologies in the 20th century were firstly that most people had access to ways of repairing consumer goods, and secondly that markets for repaired secondhand goods played an important role in the dissemination of consumer technologies. However, the ways in which people interact and intervene with things have altered over time; in particular, people have become less likely to patch and mend things and more likely to replace individual parts. The domestication of things like cars and household appliances has been reliant on emerging advice, maintenance and repair services offered by customer service departments, the development of which remains largely unresearched. ${ }^{21}$ The vanguard technologies of the 20th-century mass consumption era were products like cars, large household appliances (fridges, ovens) and also radios and televisions, all of which required regular maintenance and repair. Yet research into the history of repair, continued use or repurposing of consumer technologies has, to date, focused solely on the car as a central symbol of status and prestige, ${ }^{22}$ even though

19 Reith, Reinhold/Stöger, Georg: "Einleitung. Reparieren - oder die Lebensdauer der Gebrauchsgüter", in: Technikgeschichte 79, 3 (2012), p. 173-184.

20 Ibid.; Lenger, Friedrich: Sozialgeschichte der deutschen Handwerker seit 1800, Frankfurt a. M.: Suhrkamp 1988.

21 Reith/Stöger, "Einleitung. Reparieren”, p. 182.

22 Harper, Douglas: Working Knowledge. Skill and Community in a Small Shop, Chicago: University of Chicago Press 1987; Borg, Kevin L.: Auto Mechanics. Technology 
an estimated 110,000 people in the USA, for instance, were working in the field of radio and television repair alone in the early 1960s. But by 2006, the number of people employed in the field of "electronic home entertainment installers and repairers" had dropped to 40,000 , even though the number of televisions per household had more than doubled from 1.13 to 2.6 sets, and the number of radio sets had risen by a much higher factor. ${ }^{23}$ Shops which repaired radios in use and sold second-hand radios and televisions or other domestic electrical appliances (having purchased them, repaired them and perhaps upgraded or modified them) could be found in almost every inner-city neighbourhood in West Germany between the 1970s and the 1990s. With a handful of exceptions such as mobile phone repair shops and garment alteration services, shops like this have now all but vanished. There has been little research to date on the prevalence and evolution of these businesses, but a study carried out in 2011 found that there were just under 1,000 companies engaged in this field in Germany, employing around 36,500 people (not including car repairs, plumbing and house construction). ${ }^{24}$

Leaving to one side novel consumer devices such as mobile phones and printers, since the last third of the 20th century markets for household appliances in highly developed mass consumer societies have been saturated, which means that most people are purchasing replacements or multiples rather than acquiring appliances for the first time. An "inflation of things", ${ }^{25}$ in other words a duplication and diversification of the consumer goods owned, has also been observed. The average German household, for instance, is currently estimated to own around 10,000 objects. UK households were estimated to own around ten times as many consumer electronic devices in 2010 as they did as in 1990, and the average small kitchen in the USA now contains around 1,000 things - three times

and Expertise in Twentieth-Century America, Baltimore: Johns Hopkins University Press 2007; Lucsko, David N.: Junkyards, Gearheads, and Rust. Salvaging the Automotive Past, Baltimore: Johns Hopkins University Press 2016.

23 McCollough, John: "Factors Impacting the Demand for Repair Services of Household Products: The Disappearing Repair Trades and the Throwaway Society", in: International Journal of Consumer Studies 33, 6 (2009), p. 619-626, p. 619.

24 Poppe, Erik: Reparaturpolitik in Deutschland. Zwischen Produktverschleiß und Ersatzteilnot, ed. by SUSTAINUM - Institut für zukunftsfähiges Wirtschaften, Berlin 2014, online: http://www.reparatur-revolution.de/wp-content/uploads/Studie_Repara turpolitik-in-Deutschland-2014.pdf (accessed 21.07.2017), p. 5.

25 Heßler, Martina: "Wegwerfen. Zum Wandel des Umgangs mit Dingen”, in: Zeitschrift für Erziehungswissenschaft 16, 2 (2013), p. 253-266. 
as many as in $1950 .{ }^{26}$ Repairing a thing, or paying for someone else to repair it, appears to have become a marginalised activity when viewed in the context of this huge quantitative increase in the number of new goods purchased in rich areas of the world. Whereas previously any item could be or was repaired, now only a small percentage of the things an individual owns are likely to be regarded as objects of repair. Affluent mass consumer societies no longer expect to be able to repair all the things in their households, but instead limit their repair efforts to specific things which are regarded as valuable and worthy of preservation and repair. For example, in the German consumption culture, certain household appliances such as Miele washing machines and Vorwerk vacuum cleaners are expected to have long operating lives, and consequently are also in demand in the second-hand market. But it is almost impossible to sell CRT televisions anywhere in Germany - although some are exported. ${ }^{27}$

The act of repairing household goods is therefore inextricably linked to underlying ownership cultures and the meaning of things. But it is also more broadly related to the prevailing disposal infrastructures which allow users to dispense with things, and to the duration of timeframes over which the things are used. These latter two considerations - the disposal of things and the duration of their use - are fundamental dimensions of the ways in which we handle things, and much like the ownership and purchase of household things - have undergone a significant shift with the emergence of mass consumer society. Waste collection services, which first emerged in towns and cities before spreading to rural areas from the 1970s onwards, have made it easier for households to "throw things away". ${ }^{28}$ In the intervening decades, municipalities have also been obliged to organise separate bulky waste collection services. ${ }^{29}$ For the first time, this has allowed households to dispose of furniture, household goods and electrical appli-

26 Trentmann, Frank: Empire of Things. How We Became a World of Consumers, from the Fifteenth Century to the Twenty-First, London: Allen Lane 2016, p. 674.

27 Broehl-Kerner, Horst et al.: Second Life. Wiederverwendung gebrauchter Elektround Elektronikgeräte, edited by Umweltbundesamt, Berlin 2012, http://www.uba.de /uba-info-medien/4338.html (accessed 03.02.2017).

28 Strasser, Susan: Waste and Want. A Social History of Trash, New York: Metropolitan Books 1999; Weber, "Reste".

29 Weber, Heike: Vom Hausrat zum Sperrmüll - Sperrmüll als Phänomen der "Wegwerfgesellschaft", in: Pesch, Dorothee/Spiegel, Beate (eds.): Sparen, Verschwenden, Wiederverwenden. Vom Wert der Dinge, Oberschönenfeld: Schwäbisches Volkskundemuseum Oberschönenfeld 2017, p. 28-35. See also Weber, Heike: "Mending or Ending? Consumer Durables, Obsolescence and Practices of Reuse, Repair and Disposal in West Germany (1960s-1980s)" (this volume). 
ances which would previously have been passed on to family or friends, repurposed or taken to a second-hand shop to be resold or scrapped - with a high likelihood of repair in most cases. Alternative "disposal channels" such as secondhand shops have continued to exist, but are regarded only as viable ways of getting rid of certain categories of household goods. Books and clothes, for example, both of which are prominent illustrations of the circulation of used goods in the early-modern period, still tend not to be thrown away by most households, but instead are disposed of in second-hand shops or via clothing swaps, online services such as momox, or public bookcases. After a debate lasting almost two decades on the problem of electronic waste and its potential toxicity, manufacturers are now obliged to take back and dispose of used electrical and electronic goods. They do so by recycling the devices rather than repairing them, however. ${ }^{30}$ Beforehand - from around 1970 - large numbers of such electronic consumer appliances were regularly disposed of in normal waste bins as well as bulky waste collection systems.

A working group led by the anthropologist Nicky Gregson ${ }^{31}$ examined in closer detail the flip side of the appropriation of things, in other words the practice of their "dispossession" and removal from the household and the meaning frameworks associated with this, and coined the term "divestment" to refer to the process. The group carried out observations of everyday life in UK households with a view to identifying the extent to which household goods were cared for, preventively maintained or repaired. In each case the answer depended on the level of skill of the members of the household, the things themselves and the question of intent, i. e. whether and how users intended to carry on using them. ${ }^{32}$ Members of households were observed rubbing wooden furniture with beeswax and carrying out small-scale and large-scale repairs to furniture, but "quick fixes" were the dominant mode of repair. ${ }^{33}$ Things that were no longer repaired might be kept and stored for later use or sorted out and thrown away, marking a deliberate decision by the user to end the thing's "lifespan".

30 Laser, Stefan: "Elektroschrott und die Abwertung von Reparaturpraktiken. Eine soziologische Erkundung des Recyclings von Elektronikgeräten in Indien und Deutschland", in: Krebs/Schabacher/Weber, Kulturen des Reparierens, p. 85-103.

31 Gregson, Nicky/Metcalfe, Alan/Crewe, Louise: "Moving Things Along: The Conduits and Practices of Divestment in Consumption", in: Transactions of the Institute of British Geographers 32, 2 (2007), p. 187-200.

32 Gregson, Nicky/Metcalfe, Alan/Crewe, Louise: "Practices of Object Maintenance and Repair: How Consumers Attend to Consumer Objects within the Home", in: Journal of Consumer Culture 9, 2 (2009), p. 248-272.

33 Ibid., p. 248. 


\section{THE “LIFESPAN” OF CONSUMER PRODUCTS}

Advocates of the current repair movement are vocal about the fact that repairing a thing allows its lifespan, i.e. its time in use or in usable shape, to be extended. ${ }^{34}$ The act of repair is viewed as a transformative practice which converts shortlived things into long-lived things, and a throw-away and resource-greedy society into a sustainable and repair-oriented one. ${ }^{35}$ That said, there has been surprisingly little reflection on the concept that things have a "lifespan". Indeed, this very concept is, for the most part, an offshoot of the mass consumer society. In the late 19th century, the term "lifetime" was used in everyday parlance mainly to refer to people, plants and animals, ${ }^{36}$ but it had also made initial inroads into the fields of chemistry and technology, where it was used to describe the longevity of things such as radium, wire cables, clockwork mechanisms, light bulbs or individual components of technical devices. The idea that consumer goods have a certain predictable "lifespan" came into common currency in parallel with the rise of mass production and consumption. Indeed, modelling and calculating the likely length of a product's utilisation phase represents a core strategy and an integral part of this mode of production and consumption: manufacturers' product policies are firmly based on notions of how often and for how long things will be used, and which components or designs are most likely to pay off in financial terms, as well as considerations relating to the supply, stockpiling and price of spare parts, repairability, warranties and maintenance. The figures which manufacturers have in mind are minimum requirements rather than envisaged maximum lifespans, and durability tests are therefore usually terminated when these minimum requirements are achieved. More recently, environmentally friendly product policies have been expected to take into account not only the aforementioned technical, material and economic criteria, but also environmental criteria when identifying a product's "optimum" lifespan. ${ }^{37}$ One problem faced in this

34 See e. g. Wiens, Kyle: "Ich bin Reparateur. Ein Manifest für die digitale Revolution”, in: Baier et al., Die Welt reparieren, p. 111-118.

35 Bertling, Jürgen/Leggewie, Claus: "Die Reparaturgesellschaft. Ein Beitrag zur Großen Transformation?", in: Baier et al., Die Welt reparieren, p. 275-286.

36 Anon.: "Lebensdauer", in: Meyers Konversations-Lexikon. Ein Nachschlagewerk des allgemeinen Wissens (1885-1892), 4th ed., vol. 10, Leipzig/Wien: Bibliographisches Institut 1888, p. 589-590; Pierer, Heinrich August: "Lebensdauer", in: Pierer's Universal-Lexikon, 4th ed., vol. 10, Altenburg: H. A. Pierer 1860, p. 190-192.

37 Rubik, Frieder/Teichert, Volker: Ökologische Produktpolitik. Von der Beseitigung von Stoffen und Materialien zur Rückgewinnung in Kreisläufen, Stuttgart: SchäfferPoeschel 1997, p. 192. 
respect is that the methodologies developed and the knowledge repositories built up during the age of mass production - in fields such as material testing, utility value research, durability tests or economic product life cycle calculations - belong to the manufacturers and have, for the most part, remained locked behind their factory gates. With this in mind, it should come as no surprise that many manufacturers stand accused of implementing planned obsolescence strategies, i. e. deliberately shortening their products' lifespans.

A similar lack of transparency can be observed with regard to product lifespans on the consumer side of the equation, even though it can safely be assumed that users have a rough idea of how long they intend to use a thing before they purchase it. Few people go out and buy mass consumer goods such as washing machines, fitted kitchens or computers in the expectation that they will pass them on to their children, but it is not merely the meaning attached to a thing which determines whether it will be repaired (and therefore whether it will continue to be used); it is also whether it can be repaired and the availabilities and costs of doing so. As labour costs have substantially increased over time, purchasing a new item is often more rational in economic terms than having the old one repaired. Furthermore, even the most cursory of glances at repair manuals from eras gone by reveals that a number of domestic maintenance procedures which were still standard in the 1970 s or 1980 s have since fallen into oblivion. For example, users of that time were reminded that they should regularly open up hairdryers, shavers and handheld mixers and perform certain maintenance tasks in order to keep them in working order for as long as possible. ${ }^{38}$ Nowadays, it is largely the emotional and symbolic meaning of a thing which determines whether or not it is repaired. An OECD study published in 1982 found that consumers disposed of many household goods before they had reached the end of their useful life, a survey carried out in the USA in 1978 revealed that the majority of respondents believed that it cost too much to repair things, and studies from around the same time in Denmark and Norway highlighted the fact that over half of vacuum cleaners that were discarded were still operating correctly. ${ }^{39}$ Moreover, putting second-hand appliances back into economic circulation has become difficult in highly developed mass consumer societies because of complex safety regulations and ever-faster innovation cycles. At the same time,

38 Middel, Bernd/Müller-Steinborn, Martin: Selbst Haushaltsgeräte warten und instand setzen, Munich: Compact 1989; Weber, "Mending or Ending?".

39 Organisation for Economic Co-Operation and Development (OECD): Product Durability and Product Life Extension. Their Contribution to Solid Waste Management, Paris: OECD 1982, p. 16, 31, 35 and 93. 
complaints from consumers about lack of repairability, poor availability of spare parts and high repair costs have increased. ${ }^{40}$ Nevertheless, some things appear to become so closely entwined with the user's values and routines that they are repaired even when it costs the user more than purchasing a replacement: in a study investigating repair workshops in south-west England, examples included comfortable slippers which had been broken in to the owner's liking, or a pan which the owner used to cook porridge in a known amount of time. ${ }^{41}$

In spite of the lack of transparency hinted at above, the term "lifespan" has become widely accepted, and "rules of thumb" are even quoted in the form of approximate expected years of service, in some cases perhaps based on the Federal Ministry of Finance's depreciation tables. For example, consumers and manufacturers, both in the 1970s and today, expect cars or washing machines to last around 10 years, although the underlying assumptions regarding usage patterns, operating methods and repair strategies are not explicitly stated by any of the stakeholders involved in negotiating this figure (manufacturers, consumers, goods testers, etc.). Specifying lifespans is purported to be a means of quantifying, in "human" years, the length of time between the date on which a thing is (first) purchased by a household and the date on which it is removed from that household. Indeed, some product lifespan calculations are based directly on methods associated with demographic statistics, ${ }^{42}$ but generally speaking a wide variety of methods have emerged for determining the length of time over which things are used by their first owners, making it difficult to compare the figures obtained. In reality, countless devices defy such calculations, as they languish in cellars, drawers and garages in a transitional state between "no longer being used" and "ready for disposal", while others find themselves back on the side of reuse via informal channels.

Simply specifying a product's lifespan in years is an overly reductive way to talk about how things are used, how long they are used for, how they are repaired and how and why they are ultimately removed from households. This can also be seen by comparing different consumer societies. For example, the differing economic structures and frameworks of consumption in the Federal Republic

40 Weber, Heike: "Made to Break? - Lebensdauer, Reparierbarkeit und Obsoleszenz in der Geschichte des Massenkonsums von Technik”, in: Krebs/Schabacher/Weber, Kulturen des Reparierens, p. 49-83.

41 Bond, Steven/DeSilvey, Caitlin/Ryan, James: Visible Mending. Everyday Repairs in the South West, Devon: Uniformbooks 2013.

42 For example, see the calculation methodology from a business studies perspective in Bellmann, Klaus: Langlebige Gebrauchsgüter: Ökologische Optimierung der Nutzungsdauer, Wiesbaden: Springer 1990, p. 52-78. 
of Germany and the German Democratic Republic were associated with different underlying conditions for owning, repairing and using consumer goods, and for throwing them away, stockpiling them or passing them on. Socialist economies are often described in the literature as "repair societies", but there was a tendency in these economies for old devices not only to be repaired more frequently but also to be hoarded as a future resource, either to be swapped against something else or to be used for spare parts. ${ }^{43}$ Private cars were used for three times longer than their projected lifespan of 8-10 years in the German Democratic Republic, which also resulted in greater efforts to repair and maintain them. ${ }^{44}$ Spare car parts accounted for a significantly higher proportion of the automotive market in East Germany than in West Germany. Sometimes, however, cars had to be repaired and patched up before a new owner could even drive them because of shortcomings in production. In sum, the overall picture is more complicated than the popular perception of "long-lasting" East German designs, as illustrated for example in the 2016 documentary film Kommen Rührgeräte in den Himmel? [Do mixers go to heaven?]). ${ }^{45}$

Hans Peter Hahn recently criticised the use of "biographies of objects" as "bio-metaphors", 46 claiming that they imply a clear beginning and a distinct end to the "thing-ness" of a thing, and overlook the fact that a thing always exists in a state of interconnectedness with other things. Anthropomorphising a thing by referring to its "lifetime", or stating that it "ages" or has a second or third "life" is just as problematic, and ultimately tells us nothing about the way in which we interact with things, in other words how we use, maintain and repair them, and the practices and forms of knowledge involved in these processes. A more useful metaphor might be the idea of a cascade of use, which incorporates reuse and repurposing by a thing's new owners as well as any associated repairs and changes to the form and significance of the thing, right through to its disassembly and dismantling for spare parts - a common practice in economies of the poor - and its final disposal or even placement in a museum as a thing worthy of preservation, at which point repair becomes restoration.

43 Gerasimova, Ekaterina/Chuikina, Sofia: “The Repair Society”, in: Russian Studies in History 48, 1 (2009), p. 58-74.

44 Möser, Kurt: "Thesen zum Pflegen und Reparieren in den Automobilkulturen am Beispiel der DDR”, in: Technikgeschichte 79, 3 (2012), p. 207-226.

45 Kommen Rührgeräte in den Himmel? (2016), director: Reinhard Günzler.

46 Hahn, Hans Peter: "Dinge sind Fragmente und Assemblagen. Kritische Anmerkungen zur Metapher der 'Objektbiographie'”, in: Boschung, Dietrich/Kreuz, Patric-Alexander/Kienlin, Tobias (eds.): Biography of Objects. Aspekte eines kulturhistorischen Konzepts, Paderborn: Wilhelm Fink 2015, p. 11-33. 
For the early modern period, researchers have investigated such cascades of use in exhaustive detail, for instance for clothes ${ }^{47}$ and household goods ${ }^{48}$; these cascades led from the upper classes to the lower classes, and then ultimately to various recycling pathways when repairs were no longer possible. Over the 20 th century, it became common for cascades of use to lead from initial use in a rich country to continued use in poorer regions of the world, as in the case of radios, tape recorders, used cars or second-hand clothes ${ }^{49}$ Repair habits and distribution routes within these recent cascades of use are often poorly documented, while at the very least the more problematic among them - e. g. old electrical and electronic equipment and electronic waste - are currently coming under much criticism. ${ }^{50}$ The case of consumer electronics demonstrates the extent to which poorer regions of the world are used legally or illegally as a dumping ground for cast-offs from richer countries. In poor economies, such cast-offs might be put to use in new ways which differ from the original intended purpose of the consumer good. It is only recently that these repair cultures of the Global South have been studied in the fields of science and technology studies, ethnography and cultural sciences. ${ }^{51}$

\section{ACTORS OF REPAIR: REPAIR AS INVISIBLE WORK AND AS AN ACT OF CONSUMPTION}

A glance at the employment structure of engineers - central actors of the technical world - reveals that most engineers today are engaged in the maintenance

47 Fontaine, Laurence (ed.): Alternative Exchanges. Second Hand Circulations from the Sixteenth Century to the Present, New York: Berghahn Books 2008.

48 Stöger, Georg: Sekundäre Märkte? Zum Wiener und Salzburger Gebrauchtwarenhandel im 17. und 18. Jahrhundert, Wien: Verlag für Geschichte und Politik 2011.

49 Hahn, "Das 'zweite Leben"”; Malefakis, "Tansanier mögen keine".

50 Salehabadi, Djahane: "The Scramble for Digital Waste in Berlin", in: Oldenziel, Ruth/Trischler, Helmuth (eds.): Cycling and Recycling. Histories of Sustainable Practices, New York: Berghahn Books 2016, p. 202-214.

51 Edgerton, Shock of the Old; Verrips, Jojada/Meyer, Birgit: "Kwaku's Car: The Struggles and Stories of a Ghanaian Long-Distance Taxi-Driver”, in: Miller, Daniel (ed.): Car Cultures: Materializing Culture, Oxford/New York: Bloomsbury 2001, p. 153184; Jackson, Steven J./Pompe, Alex/Krieshock, Gabriel: "Repair Worlds. Maintenance, Repair, and ICT for Development in Rural Namibia", in: Proceedings of the 2012 Conference on Computer Supported Cooperative Work, ACM, New York 2012, p. $107-116$. 
and repair of existing things rather than the development and design of new things. David Edgerton has therefore compared the activities of engineers with the prophylactic and curative efforts of medical practitioners: "If most doctors and dentists maintain and repair human bodies, then similarly engineers are concerned with keeping things going, with diagnosis and repair of faults, as well as operations." 52 The real question, then, is why we know so little about what "repair people" do, and about the past and current significance of repair, repairability and maintenance in technical training courses and the engineering sciences. ${ }^{53}$

Our lack of knowledge about the people who carry out repairs and the knowledge they apply can be traced back to the fact that the act of repair, despite its omnipresent nature, is structurally invisible: ${ }^{54}$ if a thing has been repaired skilfully - and that is the stated goal of any act of repair -, it is no longer possible to tell that it has been repaired. ${ }^{55}$ What is more, repairs, and in particular major infrastructure repairs, often take place "behind the scenes" in order to avoid disrupting the general public. ${ }^{56}$ For example, the hours after dusk in a European city around 1900 were not just a time for revelry, but also for repairs to rail and tram lines, tarmacked streets, and all urban infrastructures ranging from railway stations and post offices to sewage plants. ${ }^{57}$

Although people who make a living by repairing things form one of the largest service industries in the world, their jobs are often socially and culturally invisible and attract little prestige. According to Susan Leigh Star and Anselm Strauss, repair practices are "invisible work", 58 and their routine and everyday nature means that they are barely perceived by users, despite the fact that they are visible in principle and necessary to guarantee the operation of industrial systems, organisations and institutions. "Repair people" take centre stage and be-

52 Edgerton, Shock of the Old, p. 100.

53 Reith/Stöger, "Einleitung. Reparieren".

54 Graham/Thrift, "Out of Order".

55 Schabacher, "Im Zwischenraum".

56 Denis, Jerôme/Pontille, David: "Material Ordering and the Care of Things", in: Science, Technology \& Human Values 40, 3 (2015), p. 338-367.

57 Schlör, Joachim: Nachts in der großen Stadt: Paris, Berlin, London 1840-1930, Munich: Artemis und Winkler 1994.

58 Star, Susan Leigh/Strauss, Anselm: "Layers of Silence, Arenas of Voice: The Ecology of Visible and Invisible Work", in: Computer Supported Cooperative Work 8, 1 (1999), p. 9-30.

59 Schabacher, Gabriele: "Medium Infrastruktur. Trajektorien soziotechnischer Netzwerke in der ANT", in: Zeitschrift für Medien- und Kulturforschung 4, 2 (2013), p. $129-148$. 
come explicit mediators of events only when a malfunction or other interruption occurs.

It should be noted, however, that the social prestige of individual repair professions has varied greatly over time and between different social and historical contexts. For example, car mechanics have been looked down on in the USA since the early days of chauffeur-mechanics in the late 19th century, with complaints often voiced about unnecessary or bungled repairs, over-inflated prices and a lack of suitable trainees. ${ }^{60}$ By way of contrast, the automotive industry in Germany has always been held in high esteem, and in the post-war decades the car repair workshop came top of the list for young men seeking apprenticeships. ${ }^{61}$ Even in pre-industrial society, the guild system of craftsmen led to social differentiation: many craftsmen not only produced goods but also repaired them, and some, such as cobblers or tailors, specialised entirely in repair services, ${ }^{62}$ but those outside the guild system - mostly journeymen not employed by a master craftsman - were stigmatised as "travelling journeymen" (Störer) or "false workers" (Pfuscher). ${ }^{63}$ Generally speaking, the social status of those who earned most of their money by repairing things, including members of ethnic or religious minorities who moved around from place to place or were based in the vicinity of second-hand markets in towns and cities, was very low. As more and more consumer goods began to be produced on an industrial scale, however, the task of repairing those goods started to dominate the working lives of craftsmen in many different trades from the late 19th century onwards. ${ }^{64}$

Pre-industrial households habitually repaired their own goods as part of everyday life and did not pay others to do so; only higher-status households delegated repair work to craftsmen. Over the course of the 20th century, the practice of repairing one's own goods fell in and out of popularity a number of times, with marked upswings during times of crisis or war. The close ties between manufacture and repair are also evident in relation to the act of self-repair. The sewing machine, for example, was first owned as a domestic means of production in the

60 Borg, Auto Mechanics.

61 Krebs, Stefan: “'Dial Gauge versus Senses 1-0'. German Car Mechanics and the Introduction of New Diagnostic Equipment, 1950-1980", in: Technology and Culture 55, 2 (2014), p. 354-389, here p. 368.

62 Bernasconi, Gianenrico: "Technische Kulturen des Uhrenreparierens: Wissen, Produktion und Materialität (1700-1850)", in: Krebs/Schabacher/Weber, Kulturen des Reparierens, p. 141-162.

63 Reith/Stöger, “Einleitung. Reparieren”, p. 178-182; Lenger, Sozialgeschichte.

64 Reith/Stöger, "Einleitung. Reparieren”, p. 180. 
late 19th century, ${ }^{65}$ before morphing into a private mending tool over the course of the 20th century. Even as recently as the 1950s, it was still sometimes used for making clothes and sometimes for mending them, and advice manuals aimed at middle-class households contained passages on what a sewing box should contain and how a sewing machine should be used. ${ }^{66}$

In the $1950 \mathrm{~s}$ and $1960 \mathrm{~s}$ - for the first time in history - repairing things oneself became a popular pastime across all social classes and was replete with new frameworks of meaning, as evidenced by the many DIY manuals, handbooks and magazines which were published with the explicit purpose of conveying the requisite knowledge to budding DIYers. The first issue of the magazine Selbst ist der Mann [Self Do, Self Have] came off the presses in 1957, for example, and television programmes dedicated solely to DIY also started to appear on people's screens, the most famous of which - Hobbythek, aired by public broadcaster Westdeutscher Rundfunk (WDR) - ran from 1974 to 2004. While in the 19th century the act of repair was largely regarded as a subaltern practice which well-to-do households delegated to servants or third parties wherever possible, the rise of a mass consumer society was accompanied by the novel idea of DIY and repair as a crafty outlet and leisure activity for men. ${ }^{67}$ The author of a lead story published in Der Spiegel in the mid-1960s noted with some bemusement that "[e]very other person seems to be busy sawing, filing, planing, drilling, painting or repairing a car." ${ }^{68}$ Shortly afterwards, the term "Heimwerken" (DIY) appeared for the first time in German-language dictionaries to describe what was, at the time, presumed to be an almost solely male preserve. ${ }^{69}$ For example,

65 Hausen, Karin: "Technischer Fortschritt und Frauenarbeit im 19. Jahrhundert. Zur Sozialgeschichte der Nähmaschine", in: Geschichte und Gesellschaft 4, 2 (1978), p. $148-169$.

66 Oheim, Gertrud: Das praktische Haushaltsbuch, Gütersloh: Bertelsmann 1954, p. 315-336; Derwanz, Heike: "Zwischen Kunst, Low-Budget und Nachhaltigkeit. Kleidungsreparatur in Zeiten von Fast Fashion”, in: Krebs/Schabacher/Weber, Kulturen des Reparierens, p. 197-224.

67 Gelber, Steven: "Do-it-yourself: Constructing, Repairing and Maintaining Domestic Masculinity", in: American Quarterly 49, 1 (1997), p. 66-112; Langreiter, Nikola/Löffler, Klara (eds.): Selber machen. Diskurse und Praktiken des "Do it yourself", Bielefeld: transcript 2017; Voges, Jonathan: "Selbst ist der Mann": Do-it-yourself und Heimwerken in der Bundesrepublik Deutschland, Göttingen: Wallstein 2017.

68 Anon.: "Die Axt im Koffer", in: Der Spiegel, 21 Apr. 1965, p. 47-59.

69 Voges, Jonathan: "(Arbeits-)Ethos der Freizeit? Do it yourself und Heimwerken und der Wertewandel der Arbeit”, in: Dietz, Bernhard/Neuheiser, Jörg (eds.): Wertewandel in Wirtschaft und Arbeitswelt. Arbeit, Leistung und Führung in den 1970er und 
the booklet Selber reparieren - aber wie? [Repair it yourself - but how?] published in 1964 provided the man of the house with a basic introduction to repairs in situations when "the pipe bursts, the tap drips or the door won't close"; his wife was entrusted only with the task of listing the repairs that needed to be done. ${ }^{70}$ DIY has become big business in the intervening decades, and homeowners are now able to purchase cheaper and pared-down versions of tradespeople's tools and select from a huge range of paint, flooring, wallpaper paste, etc. tailored to their requirements. In many cases DIY is no longer about reducing the cost of materials or labour - a key motivation back in the 1950s and 1960s - but about filling one's leisure time and feeling the satisfaction of creating something with one's own hands, making modern DIYers similar in many ways to early car drivers and radio hams. As a result of the shift in values which took place during the 1970s and 1980s, the average (male) citizen of the Federal Republic of Germany began to define himself less on the basis of his job and more on the basis of how he spent his money and his free time, meaning that the "do-ityourself" and "repair-it-yourself" movements came to represent creative opportunities for self-realisation - eventually also for women. Moreover, certain DIY enthusiasts in the 1970s began to perceive the act of repair as an opportunity for actively extending the lifespan of things, and even the popular television show ARD-Ratgeber: Technik [ARD-guide: technology] suggested looking around for second-hand components or finding spare parts at the scrapyard. ${ }^{71}$

But repairing by oneself also had its limits. The literature advised against tinkering with devices connected to the mains gas or electricity supply, for instance, stating that this should be left to experts on safety grounds and in view of the need for specialist tools and knowledge. ${ }^{72}$ In the late 1970s, a debate also arose between DIYers and professional car mechanics over whether cars which the owners had repaired themselves were roadworthy. In 1977, for example, a senior employee at TÜV-Rheinland (MOT-Rhineland) suggested banning DIY car repairs, an idea that was vehemently opposed by the magazine Selbst ist der Mann, the mouthpiece of the German DIY scene, ${ }^{73}$ in what was patently a clash between the commercial interests of the respective factions.

1980er Jahren in der Bundesrepublik Deutschland, Oldenburg: De Gruyter 2016, p. 73-94.

70 Fellensiek, Hans: Selber reparieren - aber wie?, Cologne: Buch und Zeit 1964, p. 39.

71 Stahel, Walter: Langlebigkeit und Materialrecycling. Strategien zur Vermeidung von Abfällen im Bereich der Produkte, Essen: Vulkan 1991, p. 223.

72 Fellensiek, Selber reparieren, p. 39.

73 Anon.: “Unser Kommentar", in: Selbst ist der Mann 21, 1 (1977), p. 11. 
The alternative economic and social visions of the future which entered the public consciousness in the 1970s offered yet another potential interpretation of the act of repairing a thing oneself. As commercialised as this act may have become, it was now seen as a way to oppose the current mass consumer culture by applying one's individual productive creativity and increasing the lifespan of things through repair, thereby also bringing about social change. Repair practices were of central importance for groups such as the American counter-culturalists, and the futurist Alvin Toffler coined the term "prosumer" to describe someone who not only consumes, but actively interacts with a thing. ${ }^{74}$ Even the pessimistic prophecies of the Club of Rome's Limits to Growth study made references to the act of repair as a potential way of using the earth's resources more efficiently and therefore for longer. ${ }^{75}$

When viewed in the context of the previous repair booms in the interwar period, during the DIY movement of the 1960s and within the various environmental and counter-cultural movements which have emerged since the 1970s, the repair movement of recent years appears somewhat less revolutionary than its representatives tend to assert. These earlier cultures of self-repair similarly embodied goals such as gaining autonomy, building communities and increasing sustainability. A common factor shared by these different repair cultures is the predominantly male connotation of the act of repairing a thing oneself, and the growing exclusion of fields of typically female pursuits such as sewing and darning. Although famous early female drivers such as Erika Mann or Ruth Landshoff-Yorck also repaired their own cars, ${ }^{76}$ and the DIY movement was not the exclusive domain of men, gender stereotypes remained entrenched. Furthermore, for the most part the current repair movement (for all that it seeks to politicise the act of repair) also perpetuates gender-specific divisions of labour, as observed by Daniela Rosner in her ethnographic studies: women continue to outnumber men when it comes to textile repairs, whereas the opposite is true when it comes to bolting and welding. ${ }^{77}$

74 Toffler, Alvin: The Third Wave, New York: William Morrow 1980; Rosner/Turner, "Bühnen der Alternativ-Industrie".

75 Meadows, Dennis et al.: Die Grenzen des Wachstums. Bericht des Club of Rome zur Lage der Menschheit, Stuttgart: Deutsche Verlags-Anstalt 1972, p. 149.

76 Hertling, Anke: Eroberung der Männerdomäne Automobil: Die Selbstfahrerinnen Ruth Landshoff-Yorck, Erika Mann und Annemarie Schwarzenbach, Bielefeld: Aisthesis 2013.

77 Rosner, Daniela K.: "Making Citizens, Reassembling Devices. On Gender and the Development of Contemporary Public Sites of Repair in Northern California", in: Public Culture 26, 1 (2013), p. 66-70. 


\section{REPAIR WORKERS AND THEIR KNOW-HOW}

The distinction made so far between expert and amateur repairers is not without its problems, even though this hierarchy is often perpetuated by the repairers themselves. The first of these problems is that the practices and tools of both groups have come to resemble each other, as illustrated by the "professionalisation" of DIY. Secondly, non-professional early adopters who could afford to purchase a particular thing such as a car, a radio or a home PC in some cases knew more and had more experience in dealing with that thing during its initial period on the market than professional repairers, who often could not afford such expensive consumer goods. The inextricable links between these two groups of repairers and their repair knowledge is also apparent from the repair literature: in the field of automotive repairs, for example, early manuals for experts and amateurs were either barely distinguishable from each other or identical. ${ }^{78}$

The codification of repair knowledge - in the many repair manuals, operating instructions, specialist magazines, television programmes and video tutorials - begs the question of whether this knowledge is specific to repairers and perhaps less accessible to designers, manufacturers and users. ${ }^{79}$ On the one hand, research into the sociology and history of repair emphasises the significance of formal technical knowledge, i. e. knowing how the technology to be repaired is designed and how it operates, and of having access to structured overviews of potential defects and their symptoms as found in fault trees, for example. Only when this knowledge is possessed can the repairer carry out a systematic diagnosis of faults, using a method comparable to differential diagnosis in the medical field. ${ }^{80}$ On the other hand, research highlights the fact that repairers need to have been repairing things for a significant length of time before they acquire the embodied knowledge necessary to handle the type of problems they encounter in everyday repair practice. ${ }^{81}$ Douglas Harper (1987) refers to this kind of knowledge as "working knowledge". It is by no means limited to an intuitive understanding of what needs to be done, but instead is characterised by situa-

78 Krebs, Stefan: “'Notschrei eines Automobilisten' oder die Herausbildung des KfzHandwerks in Deutschland", in: Technikgeschichte 79, 3 (2012), p. 185-206.

79 Jackson, "Rethinking Repair", p. 229.

80 Krebs, Stefan/Van Drie, Melissa: "The Art of Stethoscope Use: Diagnostic Listening Practices of Medical Physicians and 'Auto Doctors"', in: Icon - Journal of the International Committee for the History of Technology 20, 2 (2014), p. 92-114; Bernasconi, "Technische Kulturen".

81 Henke, “The Mechanics", p. 70. 
tional flexibility, namely the ability to select between different knowledge resources when interacting with objects to be repaired and work settings. This requires an intimate knowledge of different materials, designs and symptoms of faults, experienced at a sensory level. ${ }^{82}$ The diagnostic knowledge described by Harper is also closely associated with the skills of a craftsperson, since it is difficult to separate skills such as identifying damage to a shaft using only one's fingertips from those such as sensing the right torque for a screw. ${ }^{83}$

The unique nature of repair knowledge is also evinced by failed attempts to standardise and automate repair tasks. Back in the 1910s, for example, Ford introduced a flat-rate system for repair tasks in the hope of tackling customers' widespread dissatisfaction with the work done on their cars by Ford workshops, but the idea of regulating work procedures, durations and prices for individual repairs foundered in the face of day-to-day workshop operations which were resistant to rationalisation of this kind. ${ }^{84}$ In the late 1960s, it was Volkswagen's turn to try rationalising its repair systems, this time with the help of automated fault diagnosis. The Diagnosis I-System was introduced in 1968 and involved working through a series of prescribed investigations using a test bench with multiple testing devices. In 1971, this was followed by Volkswagen Computer Diagnostics, which involved the completion (in some cases without human intervention) of 88 test procedures. The twofold goal of this objectivisation of fault diagnostics was to streamline workshop operations and to restore a relationship of trust between the workshop and its customers; ultimately, however, neither goal could be achieved in the face of recalcitrant realities. ${ }^{85}$ Another move in this direction occurred in the 1970 s when attempts were made to standardise radio and television repairs in parallel to the introduction of modular designs, based on the rationale that "old-school" radio and television repair technicians would become surplus to requirements since even an unskilled amateur would be able to replace the modules. But these attempts also failed when confronted with the unpredictable and transient nature of accidents, faults and wear and tear. ${ }^{86}$ The newly invented service computer became an indispensable tool for repairers

82 Ibid., p. 66-69.

83 Harper, Working Knowledge, p. 118 and 124.

84 McIntyre, Stephen: "The Failure of Fordism: Reform of the Automobile Repair Industry, 1913-1940", in: Technology and Culture 41, 2 (2000), p. 269-299.

85 Krebs, Stefan: "Diagnose nach Gehör? Die Aushandlung neuer Wissensformen in der Kfz-Diagnose (1950-1980)", in: Ferrum - Nachrichten aus der Eisenbibliothek 86 (2014), p. 79-88.

86 See for example the foreword in Funkschau, special edition "Reparatur-Praxis" 15 (1983). 
working in this field, but it by no means reduced the amount of knowledge needed.

\section{CONCLUSIONS}

To sum up, the history of repair in Western consumer societies has not been a history of linear decline. Although new mass production methods and the changing relationship between labour and material costs made it more likely for things to be replaced instead of repaired, the dissemination and usage of emblematic consumer products like radios, televisions and automobiles also resulted in and relied upon new maintenance and repair services. Furthermore, second-hand markets for repaired and refurbished goods were essential for the successful diffusion of many consumer products.

We have identified three types of shift - societal, cultural and geographical that have shaped the history of repair practices in Western Europe and the USA. Societal shifts occurred when new actor groups started to own consumer products. For example, in the interwar period members of the upper class often repaired their automobiles out of necessity, since specialist repair shops could only be found in larger cities. And when members of the working class started to own automobiles in the post-war period, they often repaired them themselves out of economic necessity. Cultural shifts occurred when the DIY movement of the 1960s and the environmental movement of the 1970s turned repairing into a rewarding leisure activity and a more sustainable means of consumption. And geographical shifts occurred when certain repair services and second-hand markets vanished in Western societies and moved to poorer regions in Eastern Europe, Africa or Asia.

Finally, we have shown that maintenance and repair practices are intricately linked with different notions of a product's "lifespan". Over time, changing disposal infrastructures and novel discarding practices have influenced the decision of whether or not to repair consumer products and made the once prevalent "stewardship of objects" obsolete. ${ }^{87}$ However, systematic historical studies of repair, reuse and disposal practices in Western Europe and elsewhere will have to substantiate these observations.

87 Strasser, Waste and Want, p. 21. 